\title{
YARDSTICK OF AUTHENTICITY- “STANDARDS” IN THE PACKAGED DRINKING WATER INDUSTRY: AN INDIAN CONTEXT
}

\author{
KRIPA JOSE ${ }^{1} \&$ DR. MANJULA. R. IYER ${ }^{2}$ \\ ${ }^{I}$ Research Assistant (MRP-ICSSR), Bharata Mata College, \\ Thrikkakara, Ernakulam District, Kerala, India \\ ${ }^{2}$ Associate Professor, Chinmaya Vishwa Vidyapeeth, \\ Veliyanad, Ernakulam District, Kerala, India
}

\begin{abstract}
Ensuring the availability of safe and clean drinking water at a given price is the right of a consumer as well as the key responsibility of the governing authorities. This is practically enforced by the standardization authorities exclusively for the industry. In the Indian packaged drinking water industry, there are three standards namely ISI (Indian Standards Institute), FSSAI (Food Safety and Standards Authority of India) which are mandatory for Indian products and ISO (International Standards Organisation) certification which pertains to International Standardisation that makes the product eligible for export trade. This paper covers the significance, specifications for each of the standards and the major differences between them.

KEYWORDS: Packaged Drinking Water Industry, Indian Standards \& Mandatory
\end{abstract}

Received: May 10, 2019; Accepted: May 30, 2019; Published: Jun 24, 2019; Paper Id.: IJHRMRAUG20196

\section{INTRODUCTION}

The commercial packaged water manufacturing units are proliferating in the Indian market, tapping the increasing demand. Consumers require safe and clean drinking water for the right metabolism and for the proper absorption of nutrients in their body. Hence, there is a rising need to control the production and sales of packaged drinking water, to safeguard the interest of the consumers. The standardization in this respect facilitates quality assurance of the product. These standards are living documents which reflect progress in science, technology, and systems. To maintain their currency, all standards are periodically reviewed to keep pace with the need of the time. Use of the standards aids in the creation of products and services that are safe, reliable and of good quality. The standards help businesses increase productivity while minimizing errors and waste. By enabling products from different markets to be directly compared, they facilitate companies in entering new markets and assist in the development of global trade on a fair basis. The standards also serve to safeguard consumers and the end-users of products and services, ensuring that certified products conform to the minimum standards set.

The present study attempts to outline the standards followed in the packaged water industry of India and analyses the significance and features of such standardization in the industry. It also strives to identify the difference between the standards and lays suggestions for authentic product identity. The secondary sources of data which includes the websites, journal articles and periodicals provided a base for structuring the study. The three main standards identified in the study comprises of IS 14543:2016by BIS, FSSAI and ISO 22000:2018. 


\section{ISI (INDIAN STANDARDS INSTITUTE) MARK BY (BUREAU OF INDIAN STANDARDS) BIS}

ISI mark certifies that a product conforms to the Indian Standard, as per the Bureau of Indian Standards (BIS), the national standards body of India. The ISI mark is by far the most recognized certification mark in the Indian subcontinent. Its objective is to lay down quality standards for industrial and consumer goods. The name ISI is an abbreviation of Indian Standards Institute, the former name of the Bureau of Indian Standards.

The Bureau of Indian Standards (BIS) works under the aegis of Ministry of Consumer Affairs, Food \& Public Distribution, Government of India. It is established by the Bureau of Indian Standards Act, 1986 and came into effect in 1986. Its headquartered in New Delhi and is a founder member of the International Organisation for Standardization (ISO). It represents India in the International Organization for Standardization (ISO). (Menon, 1986) IS 14543:2016(other than natural mineral water) is the standard exclusively designed to lay benchmark for the packaged drinking water in the country. ISI certification is mandatory for the manufacture, sale or exhibition of packaged drinking water in India, to ensure standardization in the competitive market. (Anonymous, 2010)

IS 14543 mentions the detailed criteria which the ISI complied institutions must adhere to. It includes:

- Laboratory - A laboratory shall be suitably equipped and staffed to carry out the different tests in accordance with the methods given in the Indian standards.

- Test Records - All records of analysis and tests are to be maintained in suitable forms approved by the BIS.

- Quality Control - The Statistical Quality Control (SQC) methods may be used for controlling the quality of the product as envisaged in the Scheme. All instruments are required to be brought under calibration control, as per frequency to be decided to depending upon the usage.

- Standards Marks - the Licence shall be marked legibly and indelibly on the label of the bottle/container.

- Packing -The bottles/containers shall be supplied in secondary packaging as agreed to between the purchaser and the supplier.

- Marking -The following information shall be given legibly on each bottle. The name of the product, name and full address of the manufacturer, brand name, batch or code number, date of processing/packing, treatment of disinfection (if any), best for consumption within days or months from the date of packing, net quantity, direction for storage.

- $\quad$ Source Water - The source water used in the production of packaged drinking water may be initially tested for color, odor, taste, turbidity, $\mathrm{pH}$, total dissolved Solids, microbiological \& chemical requirements. Subsequently, its quality may be regularly assessed at least once in three months through in-house testing.

- Hygienic Condition - The source water shall be collected, processed, handled, stored, packed and marketed in accordance with the hygienic practices. (BIS, n.d.)

\section{THE FOOD SAFETY AND STANDARDS AUTHORITY OF INDIA (FSSAI)}

This standard was established under the Food Safety and Standards Act, 2006 which consolidates various acts \& orders that have hitherto handled food related issues in various Ministries and Departments. It is an autonomous body 
established under the Ministry of Health \& Family Welfare, Government of India and is headquartered at New Delhi.(National Portal of India : Government : Who's Who, n.d.) The objective of FSSAI is to protect and promote public health through regulation and supervision of food safety. It lays down science-based standards for articles of food and regulates their manufacture, storage, distribution, sale, and import to ensure availability of safe and wholesome food for human consumption.

FSSAI has been mandated by the FSS Act, 2006 for performing the following functions.

- Framing of Regulations to lay down the standards and guidelines in relation to articles of food and specifying the appropriate system of enforcing various standards.

- Laying down mechanisms and guidelines for accreditation of certification bodies engaged in certification of food safety management system for food businesses.

- Laying down procedure and guidelines for accreditation of laboratories and notification of the accredited laboratories.

- To provide scientific advice and technical support to Central Government and State Governments in matters of framing policy and rules in areas which have a direct or indirect bearing of food safety and nutrition.

- Collect and collate data regarding food consumption, incidence, and prevalence of biological risk, contaminants in food, residues of various, contaminants in foods products, identification of emerging risks and introduction of the rapid alert system.

- Creating an information network across the country so that the public, consumers, Panchayats, etc receive rapid, reliable and objective information about food safety and issues of concern.

- Provide training programs for persons who are involved in food-related business.

- Contribute to the development of international technical standards for food standards.

\section{“Clean Drinking Water"- FSSAI initiative}

This is a project aimed at disseminating information pertaining to the manufacturing/ processing of packaged drinking water to ensure transparency to consumers. It is a confidence-building exercise that ensures a consumer's right to safe and quality assured packaged drinking water. Consumers shall be able to verify the physical, chemical and microbiological safety of packaged drinking water through the system developed for the purpose. (fssai.gov.in, n.d.)

\section{ISO 22000:2018}

The International Organization for Standardization (ISO) is an international standard-setting body composed of representatives from various national standards organizations. The objective of this Standard is to specify requirements for a food safety management system in the food chain where an organization needs to demonstrate its ability to control food safety hazards to ensure safe products. (SAI Global Limited, 2005)ISO 22000:2018 is the standard specific to the packaged drinking water. As many of today's food products repeatedly cross national boundaries, International Standards are needed to ensure the safety of the global food supply chain. (International Organization for Standardization, n.d.)ISO ensures control at all stages of the food supply chain is in place to prevent food safety hazards. It provides a framework for management commitment, supplier and customer communication and continuous improvement of the food safety system. 
Thereby ensuring continual improvement through review and updating of the food safety management system. (qsci, n.d.)(Marques)

The requirements for ISO 22000 food safety management system involve the following elements:

- Interactive communication- Communication along the food chain between suppliers, customers, and regulatory authorities is essential to ensure that all relevant food safety hazards are identified and adequately controlled at each step within the food chain. This implies communication between organizations both upstream and downstream in the food chain.

- System management- The most effective food safety systems are established, operated and updated within the framework of a structured management system and incorporated into the overall management activities of the organization. This provides maximum benefit for the organization and interested parties.

- Prerequisite Programs (PRPs) - It consists of basic conditions or activities that are necessary to maintain a hygienic environment throughout the food chain suitable for the production, handling, and provision of safe products.

- Hazard Analysis and Critical Control Point (HACCP) Principles - All hazards that are expected to occur in the food chain, including hazards that may be associated with the type of process and facilities used, are identified and assessed. This hazard analysis is the key to an effective food safety management system, since conducting such an analysis assists in organizing the knowledge required to establish an effective combination of control measures. (Surak \& John G, 2005) (Hiroshi \& Ogawa) (gcert.eu, 2017)

\section{MAJOR DIFFERENCES BETWEEN ISI, FSSAI, AND ISO}

The three standards draw certain similarities; however, they are distinct in the following ways.

Table 1

\begin{tabular}{|l|l|l|}
\hline \multicolumn{1}{|c|}{ ISI } & \multicolumn{1}{|c|}{ FSSAI } & \multicolumn{1}{c|}{ ISO } \\
\hline It's an Indian standard & It's an Indian standard & It's an international standard \\
\hline $\begin{array}{l}\text { It's a mandatory standard to } \\
\text { be followed for packaged } \\
\text { drinking water in the Indian } \\
\text { market. }\end{array}$ & $\begin{array}{l}\text { It's a mandatory standard } \\
\text { to be followed for } \\
\text { packaged drinking water in } \\
\text { the Indian market. }\end{array}$ & $\begin{array}{l}\text { It's not a mandatory standard } \\
\text { to be followed for packaged } \\
\text { drinking water in the Indian } \\
\text { market. }\end{array}$ \\
\hline $\begin{array}{l}\text { Certification is given only to } \\
\text { the manufacturers of the } \\
\text { packaged drinking water. }\end{array}$ & $\begin{array}{l}\text { Certification can be given } \\
\text { to the manufacturers, } \\
\text { distributors or the service } \\
\text { organizations of the } \\
\text { packaged drinking water. }\end{array}$ & $\begin{array}{l}\text { Certification can be given to } \\
\text { the manufacturers, distributors } \\
\text { or the service organizations of } \\
\text { the packaged drinking water. }\end{array}$ \\
\hline $\begin{array}{l}\text { Certification is given only to } \\
\text { the product. }\end{array}$ & $\begin{array}{l}\text { Certification is given only } \\
\text { to the product. }\end{array}$ & $\begin{array}{l}\text { Certification is given only to } \\
\text { the system. }\end{array}$ \\
\hline $\begin{array}{l}\text { It checks the quality } \\
\text { conformity of the product. }\end{array}$ & $\begin{array}{l}\text { It checks the quality } \\
\text { conformity of the product. }\end{array}$ & $\begin{array}{l}\text { It checks the quality system } \\
\text { procedures. }\end{array}$ \\
\hline $\begin{array}{l}\text { Certification is directly } \\
\text { given and not to any } \\
\text { franchises. }\end{array}$ & $\begin{array}{l}\text { Certification is directly } \\
\text { given and not to any } \\
\text { franchises. }\end{array}$ & $\begin{array}{l}\text { Certification is not directly } \\
\text { given by ISO but through } \\
\text { franchises. }\end{array}$ \\
\hline
\end{tabular}




\section{SUGGESTIONS FOR PRODUCT IDENTITY}

The consumer's interests are safeguarded through the measures laid down by the certifying authorities. However, there exists the use of fake marking and certifications on the bottles of local origin. In order to identify the right source, one needs to be aware of the three certifications and how they are imprinted. The ISI mark on the packaged drinking water bottle appears as 'IS:14543' along with the ISI trademark symbol of approval. Further, FSSAI trademark symbol and FSSAI license number, which is a 14-digit number should be imprinted on the bottle. The ISO 22000: 2018 certification is an add on to the credibility of the company.

\section{CONCLUSIONS}

As the name implies, the packaged drinking water is supposed to be purified water free from contamination, suspended impurities, unwanted color, diseases causing micro-organism and hygienically packed with the convenience of use. To ensure this benchmark in the industry, the standards are devised by different regulatory bodies like BIS, FSSAI, and ISO. These standardization norms safeguard quality maintenance and thereby protect the interest of the consumers, who depend on packaged drinking water to meet their basic need for water. Knowing the major differences between the standards and the labeling of the same on the bottles helps in identifying the credibility of the source of packaged drinking water.

\section{REFERENCES}

1. (n.d.). Retrieved from http://gcert.eu/en/iso-22000-haccp/

2. (n.d.).Retrievedfromqsci:http://www.qsci.in/iso22000.html? gclid=Cj0KCQjw9afOBRDWARIsAJW4nvyFITzOVuSpwdQFqCOxY1-OSXI6mJyJ16FseGVhf_jVKqFFX_OV78aAg4lEALw_wcB

3. (n.d.). Retrieved from fssai.gov.in: https://safewater.fssai.gov.in/CleanWater/home

4. (2017). Retrieved from gcert.eu: http://gcert.eu/en/iso-22000-haccp/

5. Anonymous. (2010). India Slaps Licence Regulations on Packaged Drinking Water. Rhodes: Asia Pulse.

6. BIS. (n.d.). Retrieved from http://www.bis.org.in/cert/requirementsis14543.htm

7. Hiroshi, \& Ogawa. (n.d.). Sterilization and sanitation technologies in the latest food manufacture processes, Total food safety management by ISO 22000 food safety management system.

8. Divyanshu Shukla, Harsh Bodh Paliwal \& Abhishek James, Assessment of Drinking Water Quality of Different Hospitals at Allahabad, India Vol. 5(6), 15-20

9. International Organization for Standardization. (n.d.). Retrieved from https://www.iso.org/iso-22000-food-safetymanagement.html

10. Marques, V. A. (n.d.). ISO 22000:2005 - "Food safety management systems. Requirements for any organization in the food chain" Implementation in the bottled water industry.

11. Menon, C. R. (1986). Retrieved from bis: http://www.bis.org.in/bs/bisact.html

12. National Portal of India : Government: Who's Who. (n.d.). Retrieved from https://india.gov.in/govt/cabinet.php

13. SAI Global Limited. (2005). Retrieved from https://www.saiglobal.com/pdftemp/previews/osh/as/as20000/22000/220002005.pdf 
14. Surak, \& John G. (2005). ISO 22000: Requirements for Food Safety Management Systems. ASQ World Conference on Quality and Improvement Proceedings, (pp. 211-215). Seattle. 